and \$I25,000 in family income, because below that tuition is already to some degree covered through grants. So the majority of the funding goes to an income class which has never had a great deal of trouble affording higher education (at public institutions, anyway) in the first place.

\section{Policy Lessons}

The key to making income-targeted free tuition both effective and efficient is not to make the threshold too high. Even the Chilean government, once very keen on "gratuidad" for all, has belatedly come around to this realization. For budgetary reasons, the government was forced to limit its recent introduction of "free" tuition to students from families in the bottom six deciles of income. This summer, the Chilean Treasury Department published cost estimates for expansion of the program. In its present state, the cost of the fully phased program will be 607 billion pesos (about US\$950M). Adding the next four deciles raises the price by about 350 billion, or 58 percent for each decile. That is to say, free tuition for everyone would cost over 2 trillion pesos, or over three times as much as it costs for the bottom six deciles. This difference is equal to I.5 percent of GDP. And for what? The very fact that it costs so much is a reflection of the reality that participation from these groups is already so high that they do not need government help.

In short, while targeted free tuition makes lots of sense, it really does need to be targeted. If targeting weakens, the program becomes more expensive and less effective. New York's plan, clearly, suffers from insufficient targeting. The Canadian and-unintentionally-the Chilean plans have it mostly right. As more jurisdictions experiment with targeted free tuition, it will be important to grasp these lessons.

DOI: http://dx.doi.org/10.60I7/ihe.2017.91.9774

\section{Public Universities and Bud- get Cuts in Malaysia}

\section{Doria Abdullah}

Doria Abdullah is senior lecturer at UTM School of Professional and Continuing Education (UTMSPACE), Malaysia, and associate at the Observatory on Borderless Higher Education (OBHE).E-mail: doria@ utmspace.edu.my or Doria.Abdullah@obhe.org.

$\mathrm{M}$ alaysia invests heavily in education. The tertiary sector commands the largest share of the education budget. Public funding is directly disbursed to 20 public universities in the country. In 2007,90 percent of the universities' operating budgets came from the government, while the re- maining Io percent was derived from tuition fees and other self-generated income. Public funds were also allocated indirectly through scholarships, student loans, and annual stipends for individual students to purchase books, reference materials, and broadband subscriptions.

Since 2007, the Malaysian government has reduced funding for higher education. The allocation to public universities is at present reduced to 70 percent, with 30 percent of the budget covered through self-generated income. The cuts have been particularly drastic the past two years: in 20I7, public universities received a total allocation of RM 6.12 billion, which represents a i 9.23 percent drop from the RM 7.57 billion allocation received in 2016 .

These massive cuts have not been well received among Malaysia's academic community. Multiple calls were made for the government to reconsider the budget cuts, not only by vice-chancellors of public universities, but also by the public, which is concerned with the quality of higher education delivered in an environment with limited resources.

\section{RATIONALES}

It is rather convenient to use economic volatility as a justification for the current austerity measures. Fluctuating oil prices and the depreciation of the local currency, the ringgit, have reduced overall revenues and taxes, shrinking the amount of public funds available to the sector. It should be noted here that other sectors have not been spared: the healthcare sector, for example, has also experienced reduced funding in recent years.

The gradual reduction of public funding to higher education is necessary. Malaysia ranks itth out of 50 countries for resources allocated for higher education, under the Universitas 2I ranking of national higher education systems. However, the country is 39th in terms of output and impact on research, institutional excellence, and graduate employability. For a sector that receives significant public funding, returns do not meet expectations. Citing outcome-based budgeting, the government rationalizes its funding allocation to public universities, prompting them to be more efficient in their operations.

The fact remains that the Malaysian higher education sector has expanded immensely. In 20I2, there were I.2 million students undertaking postsecondary studies, and this figure is expected to increase to 2.5 million by 2025 . With a twofold expansion anticipated in the next decade, increasing public funding to support the sector is not a sustainable solution. The budget cuts come at a critical and timely moment, and public universities have to adjust to the new norm.

\section{AdJUSTMENTS}

Before the budget cuts, public universities were in a com- 
fortable financial situation, with no pressure to generate income through their core work. The funding reduction has necessitated swift changes across all functions. It started with short-term cost-cutting measures in administrative functions, travel reimbursements, and events management. Next, the institutions cut down on international faculty recruitment, academic staff mobility, and infrastructure development. This was followed by rentals and leasing of on-campus assets, increasing public consultancy services, and a push for commercialisation of R\&D together with industry.

A hike in tuition fees might be a quick way out of the financial conundrum. However, the minister of higher education has given his personal reassurance that tuition fees for domestic students will not be raised. The universities are negotiating a solution by calling for a tuition fee review, which should enable them to gradually increase fees over time, or adjusting tuition charges to a student's socioeconomic background. International students enrolled at both undergraduate and postgraduate levels pay full tuition fees, which has encouraged universities to intensify international student enrollments.

\section{Budget cuts will become a permanent fixture in the Malaysian higher educa- tion landscape.}

Universities are revisiting the functions of their alumni engagement offices, and initiating plans to better connect with their alumni networks. Contributions from the public to higher education are encouraged through endowments and waqf, donations of assets and cash contributions in accordance with Islamic principles. Universities have also set up private entities that offer market rate, full-time academic programs and a variety of professional programs to the general public. These initiatives, which are common elsewhere, are becoming integral components of Malaysian public universities.

\section{The Ministry's Agenda}

The ministry of higher education is using budget cuts to push for two transformation agendas.

The first agenda relates to governance. The board of directors, once a ceremonial and dormant structure in each public university, is now given the specific role of expediting decision-making processes. The board also performs annual assessments to evaluate their effectiveness. The five research universities-Universiti Malaya; Universiti Kebangsaan Malaysia; Universiti Putra Malaysia; Universiti Sains Malaysia; and Universiti Teknologi Malaysia-were the first group of universities that were granted financial autonomy, enabling them greater decision-making power over student enrollments, academic management, human resources, and income generation.

The second agenda relates to performance indicators and specific functions that support the financial sustainability of the universities. The performance contracts of vice-chancellors include targets on revenue generation, which affect the disbursement of future funding allocations and overall performance evaluation. Other strategic functions include the deputy vice-chancellor for development, who works with the business development unit to unlock funding opportunities for the institution, and the deputy vice-chancellor for industry and community affairs, tasked to strategically engage with external players from the industry and from communities for academic and research collaborations.

\section{UNADDRESSED GAPS}

Public universities are on a steep learning curve. Faculty and administrators are finding it hard to adapt. It will take a while to change mindsets and behaviors; many understand the need to be more efficient and innovative in generating revenue, but balk at the thought of actual implementation. Indeed, they may not have the fundamental entrepreneurial competencies to do so. Faculties and departments are risk adverse, preferring to maintain current initiatives rather than discovering new ways of doing things.

Of great concern are changes in regulatory frameworks, which do not reflect the autonomy status granted. In order to generate greater income, universities must operate more like business entities. However, public universities were established under the University and University Colleges Act of I97I (amended in 2009), and are therefore still tied to traditional structures and investments. Universities also have to navigate layers of approvals and paperwork required by the ministry of higher education, the ministry of finance, and the Economic Planning Unit concerning budget allocations, procurements, and other financial matters.

Budget cuts will become a permanent fixture in the Malaysian higher education landscape. The country could well take advantage of the current financial situation as an opportunity to transform public universities, which have to get used to leaner and more efficient operations, while maintaining or increasing existing allocations for academic and research activities. Additionally, the time is ripe for public universities to explore the uncharted territory of transnational education (TNE), working with private and foreign institutions to expand access to academic programs 
through innovative TNE models. DOI: http://dx.doi.org/Io.60I7/ihe.20I7.9I.10054

\section{Another Missed Opportuni- ty? Underfunding Australian Higher Education}

\section{Anthony Welch}

Anthony Welch is professor of education at the University of Sydney, Australia, and "Haiwai Mingshi" and PhD supervisor at Tianjin University, China.E-mail: anthony.welch@sydney.edu.au.

$\mathrm{T}^{\mathrm{i}}$ he recent set of budget reforms proposed by the Australian federal government will only compound the existing funding problems experienced by the higher education sector. Some of the worst cuts proposed by a previous minister have now been abandoned, an acknowledgement that they would never gain the approval of parliament. But it is hard to disagree with the conclusion of the vice-chancellor of a major Australian university that, while that particular crisis has been averted, the current set of proposals represent another missed opportunity to adequately fund higher education.

Government funding to the sector in Australia has fallen by 4 percent over the decade 1996-2006, while OECD data reveal that funding for higher education across member countries has risen by an average of 49 percent over the same period. There was an expectation within the higher education sector that the new prime minister, a supposed reformer whose campaign centerpiece was the need for the nation to prioritize science and innovation, would substantially raise funding for higher education and research. With at least two Nobel prizes in medicine in recent times, and internationally leading achievements in diverse fields such as solar cell technology, biotechnology, and quantum computing, it could reasonably be expected that government would reverse previous funding cuts, adequately fund the sector, and fulfil earlier promises to support the full cost of research. The leading, research-intensive "Group of Eight" universities, for example, which consistently win the lion's share of research funding, had long complained that successive governments' failure to fund the full costs of research meant an increasing pressure on their research budgets.

\section{The Proposed Reforms}

Despite such reasonable expectations, the sector was to be sadly disappointed at proposed measures that, rather than redressing past failures, arguably compounded them. A key reform was to reset the balance between public and private debt proportions that supported the longstanding national income-contingent loans scheme. Under existing arrangements, students are liable for 42 percent of the cost of their degree, an amount that is triggered only if the students meet specific conditions: graduating, gaining a job, and earning an amount above an annual income threshold. Once all these conditions are met, graduates pay an additional modest amount of income tax until the debt is cleared. Under the new arrangements, students would pay more, contributing an additional I.82 percent each year between 2018 and 202I for an ultimate total of 7.5 percent. This means that from 202I, students would be paying 46 percent, instead of 42 percent, of the costs of their degree.

It remains to be seen if the proposed shift of the cost burden toward students deters some from enrolling, particularly those from the more vulnerable groups in society. Could the proposed reforms make higher education less attractive, and perhaps even prohibitive, for some groups of students, particularly those studying part-time? The architect of the original funding scheme estimated that it should not have a great impact on student debt, adding only about a year to the time it takes students to repay their loans. Much more significant is the substantial reduction in the income threshold at which loan repayments begin-from $\$ 55,000$ to $\$ 42,000$-although cuts to the rate of collection of the debt from 4 percent to I percent would mean that the effects on most students will be relatively small.

Beyond changes to the student loans scheme, universities would be hit with a direct cut of almost AU $\$ 400$ million-AU $\$ 384.2$ million over two years-in the form of an "efficiency dividend" to the Commonwealth Grant Scheme. This so-called efficiency measure is a convenient euphemism for reduced funding, and adds to the ongoing failure by government to fund the full costs of research. If implemented, the proposed cuts would represent an overall decline in government funds of 2.5 percent in 2018 and a further reduction of 2.5 percent in 2019 . The full package, it has been estimated, would reduce public funds to the sector by almost AU $\$ 2.0$ billion over five years from 20I6-20I7. When combined with changes to the way that university grants would be indexed, it is clear that the intention is that universities would receive a smaller amount of funding per student, and would thus need to do more with less. Clearly, this is no solution to the funding problem; in fact, it would only aggravate a condition under which universities have been languishing for some time.

\section{THE NONREForms}

Abandoned in the current set of proposals were the worst elements of the earlier, deregulatory budget for higher edu- 